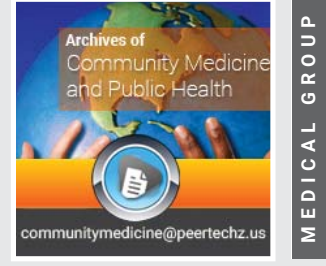

\title{
Child sexual abuse: Listening to the victims
}

\author{
Margarita Ortiz-Tallo ${ }^{1,2 *}$ and Isabel Calvo ${ }^{2}$ \\ ${ }^{1}$ Psychology Faculty, University of Málaga, Spain \\ ${ }^{2}$ Asociación Con.Ciencia, Escuela de Psicoterapia y Creatividad, Málaga, Spain
}

Received: 29 June, 2020

Accepted: 10 July, 2020

Published: 11 July, 2020

*Corresponding author: Margarita Ortiz-Tallo, PhD, Psychology Faculty, University of Málaga, Spain, E-mail:mortiztallo@uma.es

Keywords: Child sexual abuse; Sexual violence; Maltreatment; Health professionals

https://www.peertechz.com

Check for updates

\begin{abstract}
Child Sexual Abuse (CSA) is a global public health concern. We present real testimonies of adults recalling their childhood, clinical reflections and scientific research data. Patients' testimonies bring professionals closer to understanding their painful reality. All testimonies are from women who gave their consent to use their statement. Doctors and health professionals need to know this reality and be prepared to prevent and cope with abuse.
\end{abstract}

\section{Child sexual abuse}

"He was an evil spirit disguised as a golden boy, a Harry Potter Dementor. Charming, witty, handsome, intelligent, cruel, manipulative, evil and perverted. He robbed me of my childhood and innocence, my peace of mind and my security. In return he left me an infinite sadness, a feeling of deep despair, and truly awful flashbacks which continued to haunt me as an adult. He was my father."

Child sexual abuse (CSA) is a serious type of children maltreatment and is classified as violence even if the abuser does not physically harm the child. CSA should be considered a global public health concern. Public health aims to provide maximum benefit for the largest number of adults and children and reducing violence and its consequences is one of its priorities.

The World Health Organization (WHO) defines CSA as the "involvement of a child in sexual activity that he or she does not fully comprehend, is unable to give informed consent to, or for which the child is not developmentally prepared and cannot give consent, or that violates the laws or social taboos of society" [1]. UNICEF estimates that 120 million children are or have been abused during their childhood [2].

\section{Perpetrators}

"I was five years old when I told my mum. She didn't want to believe me because it implied confronting her family and that was too much for her, so she looked the other way whilst my uncle abused me and I sank into a deep depression for years."
The abuse is usually perpetrated by someone close to the child, someone they trust. Studies indicate that abusers are often people from the victims' surroundings: friends of the family, educators or family members [3]. All the reviewed studies agree that perpetrators are mostly male, and victims are more often, but not exclusively, female [1].

\section{Victims}

"I was eight, I voiced it in a family reunion in front of my mum, grandma, aunties, cousins... no one did anything. It's a complex subject, no one stood by us. It was something that also used to happen to my cousin and one of my sisters, with the same person; my grandpa. No one reacted; many years have passed before I've been able to talk about this."

Putnam [4], found a mean age of nine years old for the first episode. The majority of researchers reported that sexual abuse is most prevalent between the ages of six and thirteen. CSA is steeped in a culture of secrecy and silence [1].

\section{Disclosure and guilt}

"All my life I've felt guilty for what happened. I always thought I allowed it to happen back then. Now, at 40 and after much therapy, I've been able to comprehend that I am not to blame."

"My silence lasted many years. It was really tough to keep that experience to myself. When I finally managed to speak with someone about it I felt relief and realised it wasn't my fault." 
It is very difficult for children to reveal what's happening to them. Very often this is because they feel they are to blame [1]. A clear pattern of abuse can be seen in practice: confidence, trust, secrecy, guilt and silence. Furthermore, abuse does not tend to be an isolated incident; it tends to be a behaviour maintained throughout extended periods of time, often until late adolescence [5].

\section{Consequences}

"I've spent all my life with anxiety, depression and eating disorders"

"I've had serious sexual issues with my partner".

"I tend to be attracted to problematic men and have been in two abusing relationships as an adult"

"I've always been ill and visiting doctors with many different issues".

CSA can lead to serious consequences throughout the lives of victims. The consequences could be immediate and longterm. These include physical injury, sexually transmitted infections, emotional trauma, personality disorders, anxiety, depression and somatoforms disorders $[6,7]$.

Many victims present severe physical symptoms during their lives. Many times it is the body which asks for help through illness. So medical and psychology professionals must be prepared to detect and support victims of CSA. Doctors and therapist in general may have the opportunity to detect sexual abuse in minors and also to appreciate the consequences for adults of sexual abuse in their childhood $[1,8]$.

\section{Transgenerational}

"When I was nine, I told my aunt but she said nothing. I never spoke about it again until I was 30. During therapy, as an adult, I've learnt that my aunt and mother were also abused by the same family member".

Sexual violence can be perpetuated from one generation to another, being reported to therapists in clinical contexts. This trauma is frequently transmitted through generations with the secrets somatized in the victim's body [9]. Dissociative amnesia and difficulty recognising the signs of abuse lead to women with a previous case of CSA not realising the possibility that their children could be abused too, sometimes even leaving them in the care of the perpetrator. Early trauma produces neuronal [10], structural [11] and functional alterations within the brain, leading to a deficit in mentalization capabilities [12].

\section{Conclusions}

CSA is a type of maltreatment that produces physical and psychological effects. The victims are most often girls and perpetrators are mostly male, frequently from the victims surroundings. Guilt and secrecy accompany the victims for years and when they share their secret, adults are sometimes not prepared to face what they hear from children sexually abused.
The medical and psychology professionals' experiences show that it is of the utmost importance for society to have cognisance of this act of maltreatment and shine a light on it.

Adults and children need to be prepared and informed [13] In particular doctors, health professionals in general, educators, and law enforcement professionals (lawyers, prosecutors and judges) must be prepared to properly deal with this type of maltreatment. If professionals are not well trained to detect, report and/or prevent child abuse, then minors will have no protection. It is the professional's responsibility to be trained and to prepare everyone surrounding the victim to help them deal with such a difficult experience. Training professionals and educators, information to children and families, are essentials to move forward and provide resources to reduce child sexual abuse.

Our team works with children to prevent abuse. We develop resources using creative techniques to reach minors (and adults) through their emotions: theatre, puppets and cartoons. We also conduct research and training. We encourage professionals to be prepared to face CSA.

Finally, considering abuser's prevention Sex Offender Therapy Programs would be another important and complementary way to prevent CSA [14].

\section{References}

1. World Health Organization (2003) Guidelines for medicolegal care for victims of sexual violence. Geneva: World Health organization. Link: https://bit.ly/38HfnGJ

2. UNICEF (2019) Sexual Violence against children. Child protection from violence, exploitation and abuse. Link: https://bit.ly/3egAzEy

3. Finkelhor D, Shattuck A (2012) Characteristics of crimes against juveniles. Durham NH: Crimes against Children Research Center. Link: https://bit.ly/3eh6dBC

4. Putman FW (2013) Ten-year research update review: Child sexual abuse. J Am Acad Child Adolesc Psychiatry 42: 269-278. Link: https://bit.ly/2CqPBKs

5. Redondo C, Ortiz MR (2005) El abuso sexual infantil. Boletín de la Sociedad de Pediatría de Asturias, Cantabria y Castilla y León 45: 3-16. Link: https://bit.ly/2W4Ngw5

6. Hornor G (2010) Child sexual abuse: Consequences and implications. Pediatr Health Care 24: 358-364. Link: https://bit.ly/3256a9U

7. Münzer A, Fegert JM, Goldbeck, L (2016) Psychological symptoms of Sexually Victimized Children and Adolescents Compared With Other Maltreatment Subtypes. J Child Sex Abus 25: 326-346. Link: https://bit.ly/3fi4j54

8. Mathews B, Collin-Vézina D (2017) Child Sexual Abuse: Toward a Conceptual Model and Definition. Trauma Violence Abuse 20: 131-148. Link: https://bit.ly/329KMjT

9. Kaës R (1996) Introducción al concepto de transmisión psíquica en el pensamiento de Freud. In R Kaës, H Faimberg, M Enriquez \& J Baranes, Transmisión de la vida psíquica entre generaciones. Buenos Aires: Amorrortu $31-46$.

10. LeDoux JE (2015) Feelings: What Are They \& How Does the Brain Make Them? American Academy of Arts \& Sciences, 144: 96-111. Link: https://bit.ly/3iSG7c2

Citation: Ortiz-Tallo M, Calvo I (2020) Child sexual abuse: Listening to the victims. Arch Community Med Public Health 6(2): 135-137. 
11. Francati V, Vermetten E, Bremner JD (2007) Functional neuroimaging studies in posttraumatic stress disorder: review of current methods and findings. Depress Anxiety 24: 202-218. Link: https://bit.ly/2ZZzqw9

12. Fonagy $P$, Target $M$ (2000) Mentalization and personality disorder in children: A current perspective from the Anna Freud Centre. In T Lubbe (ed.) The Borderline Psychotic Child. London: Routledge 69-89. Link: https://bit.ly/2W6amST
13. Ferragut M, Rueda $P$, Cerezo MV, Ortiz-Tallo M (2020) What Do We Know About Child Sexual Abuse? Myths and Truths in Spain. J Interpers Violence 1-19. Link: https://bit.ly/2BPC5Au

14. Wild T, Müller I, Fromberger P, Jordan K, Klein L, et al. (2020) Prevention of Child Sexual abuse: Preliminary results from an out patient therapy program. Frontiers in Psychiatry. Link: https://bit.ly/3ff7qe8

\section{Discover a bigger Impact and Visibility of your article publication with}

\section{Peertechz Publications}

\section{Highlights}

* Signatory publisher of ORCID

* Signatory Publisher of DORA (San Francisco Declaration on Research Assessment)

* Articles archived in worlds' renowned service providers such as Portico, CNKI, AGRIS, TDNet, Base (Bielefeld University Library), CrossRef, Scilit, J-Gate etc.

* Journals indexed in ICMJE, SHERPA/ROMEO, Google Scholar etc.

* OAI-PMH (Open Archives Initiative Protocol for Metadata Harvesting)

* Dedicated Editorial Board for every journal

* Accurate and rapid peer-review process

- Increased citations of published articles through promotions

* Reduced timeline for article publication

Submit your articles and experience a new surge in publication services (https://www.peertechz.com/submission).

Peertechz journals wishes everlasting success in your every endeavours.

Copyright: @ 2020 Ortiz-Tallo M, et al. This is an open-access article distributed under the terms of the Creative Commons Attribution License, which permits unrestricted use, distribution, and reproduction in any medium, provided the original author and source are credited. 